\title{
A comparative study of the effects of programmed labour protocol and expectant management of labour
}

\author{
Anjuman Alam*, Swapnil Goswami
}

Department of Obstetrics and Gynecology, Assam Medical College and Hospital, Dibrugarh, Assam, India

Received: 06 October 2017

Accepted: 04 November 2017

\section{*Correspondence:}

Dr. Anjuman Alam,

E-mail: dr.anjuman.alam@gmail.com

Copyright: (c) the author(s), publisher and licensee Medip Academy. This is an open-access article distributed under the terms of the Creative Commons Attribution Non-Commercial License, which permits unrestricted non-commercial use, distribution, and reproduction in any medium, provided the original work is properly cited.

\begin{abstract}
Background: Childbirth is one of the most wonderful and anticipated moments in a woman's life. But the excruciating pain associated with labour makes it a really undesirable one. Objective of present study was to compare the effects of programmed labour protocol and expectant management of labour.

Methods: A clinical study was conducted on 120 low risk primigravida, 60 of them were managed with programmed labour protocol (group A) and the rest 60 (group B) were managed expectantly. Primary parameters were pain relief and changes in the mean duration of labour. Secondary parameters were changes in the amount of blood loss and APGAR score of delivered babies.

Results: Among group A, $25 \%$ had good pain relief, $60 \%$ had moderate pain relief, $15 \%$ had mild pain relief and $0 \%$ had no relief of pain. The mean duration of labour from active phase through third stage in group A was $234.27 \pm 50.38$ minutes and $304.58 \pm 41.72$ minutes in group B. The average blood loss during labour was $89.33 \pm 19.06 \mathrm{ml}$ in group A and $142.15 \pm 32.27 \mathrm{ml}$ in group B. In group A, 4 babies had APGAR score less than 7 at 1 minute, but had score more than 7 after 5 minutes following resuscitation. In group B, 9 babies had APGAR less than 7 at 1 minute. Of these, 6 babies had score more than 7 after 5 minutes following resuscitation. 3 babies had score less than 7 even after 5 minutes and were shifted to neonatal ICU.

Conclusions: Programmed labour protocol is an effective method to reduce the deleterious effects of labour on both mother and foetus.
\end{abstract}

Keywords: APGAR score, Management of labour, Programmed labour protocol, Pain relief

\section{INTRODUCTION}

Childbirth is one of the most wonderful and anticipated moments in a woman's life. But the excruciating pain associated with labour makes it a really undesirable one. Besides the highest measurable degree of pain, labour predisposes a woman and her baby to a whole lot of unwanted and undesirable complications. It is well established that prolonged labour predisposes a woman to infection, dehydration, acidosis and exhaustion as well as foetal distress and increased morbidity of the baby. Excruciating pain of labour also causes autonomic overstimulation in the mother thereby causing disturbances in circulation and respiration, and also predisposes to dysfunctional labour compromising fetal oxygenation. Freedom of pain improves both maternal and fetal outcome. ${ }^{1}$ Though there are many a method to provide labour analgesia, most of them require presence of experts and high facility centres. Epidural analgesia has been found to be highly effective in pain mitigation in labour. $^{2}$ But administration of epidural analgesia requires expert hands. Ketamine, a dissociative anesthetic, is gaining popularity as it provides excellent pain relief and patient satisfaction. ${ }^{3}$ In developing countries like ours with such a huge population and a low doctor population ratio, it is difficult to provide expert service for every 
parturient complaining of labour pain. Therefore, it is essential to provide analgesia through more simpler and viable means.

Programmed labour is an indigenously developed protocol for labour management (Daftary et al), aimed at providing pain relief during labour and optimizing obstetric outcome. ${ }^{4}$ The protocol developed by Daftary et al at the Nowrosjee Wadia Maternity Hospital, Mumbai over a period of many years rests on the three pillars of ensuring adequate uterine contractions, providing optimum pain relief and close clinical monitoring of labour events with a Partograph.

A number of studies on this protocol have revealed that patients treated with the protocol had progressive, shorter and more comfortable labour. The duration of the third stage of labour was much shorter and the blood loss was drastically reduced.

The aim of the study is to see the effects of programmed labour protocol on pain relief during labour, duration of labour, blood loss during labour and APGAR score of delivered babies, and to compare them with the effects of expectant management of labour.

\section{METHODS}

We conducted a clinical study in the Department of Obstetrics and Gynecology, Assam Medical College and Hospital, Dibrugarh during the period between July 2015 and June, 2016. 120 women were selected, in random, in the study as per inclusion and exclusion criteria. Patients were divided into group A (included in the study) and group B (where labour was managed expectantly) at random using lottery.

60 women were managed by the programmed labour protocol (group A) and the other 60 women were managed expectantly (group B).

\section{Inclusion criteria}

Low risk primigravida with singleton pregnancy at term with vertex presentation and in active labour with well effaced cervix and engaged head.

\section{Exclusion criteria}

Any obstetric risk factor (antepartum haemorrhage, malposition, malpresentation, $\mathrm{Rh}$ isoimmunisation, pregnancy induced hypertension, gestational diabetes, foetal growth restriction, cephalopelvic disproportion, foetal distress, etc) or maternal medical or surgical illness.

Informed consent was taken for all the women included in the study. All of them had undergone detailed clinical examination, including history taking, general physical examination and obstetric examination (both abdominal and vaginal). All necessary investigations were also done.

In group $\mathrm{A}$, at the onset of active labour with satisfactory heart rate pattern, amniotomy was done to confirm clear liquor. An intravenous Ringer's lactate fluid was started. Inj. Pentazocine $6 \mathrm{mg}$ and inj. Diazepam $2 \mathrm{mg}$ were mixed with $10 \mathrm{ml}$ of normal saline and injected slowly intravenously to initiate pain relief. It was followed by intramuscular administration of inj. Tramadol $1 \mathrm{mg} / \mathrm{kg}$ body weight. Inj. Drotaverine $40 \mathrm{mg}$ was given intravenously and repeated 2 hourly if required for a maximum of three doses. If contractions were not adequate (3-4 sustained contractions/10 minutes), labour was augmented by 2 units of inj. Oxytocin in $500 \mathrm{ml}$ of $\mathrm{R} / \mathrm{L}$ at the rate of 16 drops per minute (i.e $4 \mathrm{mIU} / \mathrm{min}$ ) which was gradually increased up to a maximum of 16 $\mathrm{mIU} / \mathrm{min}$ until at least 3-4 contractions every 10 minutes lasting at least 35 - 45 seconds got established.

In the group B, labour was monitored and managed expectantly as per hospital practices without using programmed labour protocol.

WHO modified Partograph was used in both the groups, where all the maternal vital parameters including progress of labour, medications used and fetal heart rate were documented. Duration of active phase, second stage and third stage of labour were recorded. Active management of third stage of labour was done in both the groups as per WHO protocol.

Blood loss was assessed by counting the number of linen towels used and weighing them before and after soakage with blood. APGAR scores at 1 and 5 minutes were assessed. If APGAR score of the baby was found to be satisfactory (7-10), it was handed over to the mother for early breast feeding. But if baby was found to be depressed $(<7)$, it was shifted to neonatal care unit under care of paediatrician.

Pain Relief Score among group A was noted postpartum after they were fully awake and scoring given from 0 to 3 (Score 0 - No relief of pain, Score 1 - Mild relief of pain, Score 2 - Moderate relief of pain, Score 3-Good relief of pain). Maternal side effects of drugs (tachycardia, nausea, vomiting, drowsiness, loose stool, fever) were recorded, if any. Following normal vaginal delivery, the mother was kept in the labour ward for at least 2 hours for observation. After 2 hours, she was re-evaluated and shifted to post natal ward when stable. Follow up was done of both mother and baby in the post- natal ward until discharge of both. Haemoglobin estimation of mother was done in the post natal ward after 24 hours of delivery.

\section{Statistical analysis}

The SPSS version-16 was used to analyse data obtained from the study. Student's t-test and Chi-square tests were 
applied. Data were presented in terms of percentage and Mean \pm Standard deviation.

\section{RESULTS}

There was significant difference in all the parameters $(\mathrm{t}-$ test). There was, however, no significant difference in the requirement for Oxytocin augmentation between group $\mathrm{A}$ and group B (chi-square test).

Table 1: The differences in mean age, mean duration of pregnancy and number of booked/un-booked patients between group $\mathrm{A}$ and $\mathrm{B}$.

\begin{tabular}{|llll|}
\hline Characteristic & $\begin{array}{l}\text { Group A } \\
(\mathrm{n}=60)\end{array}$ & $\begin{array}{l}\text { Group B } \\
(\mathrm{n}=60)\end{array}$ & $\begin{array}{l}\mathrm{p} \text { - } \\
\text { value }\end{array}$ \\
\hline $\begin{array}{l}\text { Age in years } \\
\text { (Mean } \pm \text { SD) }\end{array}$ & $24.85 \pm 2.94$ & $24.93 \pm 2.84$ & $>0.05$ \\
\hline $\begin{array}{l}\text { Duration of pregnancy } \\
\text { (Mean } \pm \text { SD) }\end{array}$ & $38.91 \pm 1.18$ & $38.48 \pm 1.36$ & $>0.05$ \\
\hline $\begin{array}{l}\text { Booked/Un-booked } \\
\text { patients }\end{array}$ & $38 / 22$ & $37 / 23$ & $>0.05$ \\
\hline
\end{tabular}

Values were comparable in both the groups (t-test).

Table 2: Pain relief score among group A (included in programmed labour).

\begin{tabular}{|lllll}
$\begin{array}{l}\text { Pain } \\
\text { relief } \\
\text { score }\end{array}$ & $\begin{array}{l}0 \text { (no } \\
\text { relief) }\end{array}$ & $\begin{array}{l}1 \text { (mild } \\
\text { relief) }\end{array}$ & $\begin{array}{l}2 \text { (moderate } \\
\text { relief) }\end{array}$ & $\begin{array}{l}3 \text { (good } \\
\text { relief) }\end{array}$ \\
$\begin{array}{l}\% \text { of } \\
\text { cases }\end{array}$ & 0 & 15 & 60 & 25 \\
\hline
\end{tabular}

Table 3: The differences in the duration of active phase, second stage and third stage of labour, rate of cervical dilatation and blood loss in labour in group $\mathrm{A}$ and $B$.

\begin{tabular}{|llll|}
\hline $\begin{array}{l}\text { Characteristics } \\
(\mathrm{n}=60)\end{array}$ & $\begin{array}{l}\text { Group A } \\
(\mathrm{n}=60)\end{array}$ & $\begin{array}{l}\mathrm{p} \text { - } \\
\text { value }\end{array}$ \\
$\begin{array}{l}\text { Duration of active } \\
\text { phase in minutes } \\
\text { (Mean } \pm \text { SD) }\end{array}$ & $186.60 \pm 51.25$ & $242.17 \pm 40.31$ & $<0.05$ \\
$\begin{array}{l}\text { Duration of second } \\
\text { stage in minutes } \\
\text { (Mean } \pm \text { SD) }\end{array}$ & $41.23 \pm 9.50$ & $54.35 \pm 12.55$ & $<0.05$ \\
\hline $\begin{array}{l}\text { Duration of third } \\
\text { stage in minutes } \\
\text { (Mean } \pm \text { SD) }\end{array}$ & $6.27 \pm 2.85$ & $8.07 \pm 3.97$ & $<0.05$ \\
$\begin{array}{l}\text { Rate of cervical } \\
\text { dilatation in cm/hr } \\
\text { (Mean } \pm \text { SD) }\end{array}$ & $2.06 \pm 0.52$ & $1.52 \pm 0.26$ & $<0.05$ \\
\hline $\begin{array}{l}\text { Blood loss in } \\
\text { labour in ml } \\
\text { (Mean } \pm \text { SD) }\end{array}$ & $89.33 \pm 19.06$ & $142.15 \pm 32.27$ & $<0.05$ \\
\hline $\begin{array}{l}\text { Oxytocin } \\
\text { augmentation }(\%)\end{array}$ & 6.7 & 8.3 & $>0.05$ \\
\hline
\end{tabular}

Among group A, 91.67\% had normal vaginal delivery, $5 \%$ delivered by outlet forceps and $3.33 \%$ had caesarean section. Among group B, $85 \%$ had normal vaginal delivery, $8.33 \%$ delivered by outlet forceps and $6.67 \%$ had caesarean section. In group A, 4 babies had APGAR score less than 7 at 1 minute, but had score more than 7 after 5 minutes following resuscitation. In group B, 9 babies had APGAR score less than 7 at 1 minute. Of these, 6 babies had score more than 7 after 5 minutes following resuscitation. 3 babies had score less than 7 even after 5 minutes and were shifted to neonatal ICU. The difference in APGAR scores at 5 minutes between the two groups was significant. Maternal side effects of drugs used in Programmed Labour Protocol were minor and included tachycardia in $3.33 \%$, nausea in $3.33 \%$, vomiting in $5 \%$ and drowsiness in $1.66 \%$ of cases.

\section{DISCUSSION}

In this study, the effects of Programmed Labour Protocol on the mother and foetus were studied on a wide range of parameters and the same were compared with those in expectant management of labour. Both group A and group B, selected in random, were comparable in age and duration of pregnancy. Mean duration of labour from active phase through third stage was found to be significantly less using this protocol, with faster rate of cervical dilatation.

Mean total duration of labour among group A was 234.27 \pm 50.38 minutes in this study. Daftary SN et al had a mean total duration of labour of 239.5 minutes in their study patients. ${ }^{4}$

Blood loss was also found to be significantly less than with expectant management. Mean blood loss among group A in this study was $89.33 \pm 19.06 \mathrm{ml}$. Active management of third stage of labour was done as per WHO protocol. ${ }^{5}$ Bhagat $\mathrm{N}$ et al got a value of $86 \mathrm{ml}$ in their study. ${ }^{6}$ Daftary SN et al and Jyoti $\mathrm{M}$ et al also noted less blood loss in their patients managed by programmed labour., 4

In this study, 25\% had good pain relief, $60 \%$ had moderate pain relief, $15 \%$ had mild pain relief and $0 \%$ had no pain relief. Good relief of pain in $37 \%$, moderate relief in $48 \%$ and mild pain relief in $15 \%$ was found in the study by Mir S et al. ${ }^{8}$ Daftary SN et al noted excellent pain relief in $70 \%$, substantial relief in $62 \%$ and insufficient pain relief in $14 \%$ of their study group; they had additionally used inj. Ketamine when required. ${ }^{4}$ Jyoti $\mathrm{M}$ et al noted good pain relief in 54\% and Manoj A et al in $70 \%$ of their study cases. ${ }^{7,9}$

Vaginal delivery rate was higher $91.67 \%$ in present study group with faster cervical dilatation, may be due to Drotavarine and pain relief achieved by programmed labour. Daftary SN et al noted the rate of vaginal delivery $88 \%$, Jyoti $\mathrm{M}$ et al in $86.66 \%$, Yuel VI et al in $98 \%$ and

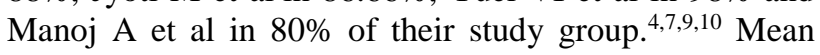
cervical dilatation rate in our study was $2 \mathrm{~cm} / \mathrm{hour}$; Daftary $\mathrm{SN}$ et al observed $2.5 \mathrm{~cm} /$ hour. $^{4}$ 
Babies born to mothers who were treated with Programmed Labour Protocol showed better APGAR scores at 1 and 5 minutes. The number of instrumental delivery and caesarean delivery were reduced and that of normal vaginal delivery increased.

Oxytocin augmentation was required in lesser number of women. Maternal side effects of drugs included two cases of tachycardia, two cases of nausea, three cases of vomiting and one case of drowsiness in this study. Kshirsagar NS et al had tachycardia in 4 cases, nausea in 6 cases, vomiting in 6 cases and drowsiness in 4 cases. ${ }^{6}$ Doses of medications used (inj. Pentazocine, inj. Diazepam, inj. Tramadol and inj. Drotaverine) in this protocol were the same as those used in various other studies on this protocol. ${ }^{4,6,9}$ They have been found to be devoid of any major side effects in mothers as well as babies.

\section{CONCLUSION}

This study based on Programmed Labour Protocol has shown some very positive results as far as the objectives and the parameters that were considered prior to the study. Use of this protocol among low risk primigravidas at term pregnancy in active labour has reduced the mean duration of labour, lesser blood loss during labour, improvement of APGAR scores among newborns and better pain relief during labour.

Due to its simplicity and cost effectiveness, this protocol should be of great help in a resource poor country like ours. Additionally, use of a Partograph will help in early identification of prolonged labour or foetal distress, early referral to a higher centre and prevention of maternal and infant morbidity and mortality. Authors can thus conclude that the use of Programmed Labour Protocol has beneficial effects on both mother and baby.

\section{ACKNOWLEDGMENTS}

Authors would like to thank the Department of Obstetrics and Gynecology, Assam Medical College and Hospital, Dibrugarh, Assam.

Funding: No funding sources Conflict of interest: None declared
Ethical approval: The study was approved by the Institutional Ethics Committee

\section{REFERENCES}

1. Rudra A. Pain relief in labour: review article. Update in Anaesthesia. 2004;18:6-11.

2. Cunningham FG, Leveno KJ, Bloom SL. Williams Obstetrics, 23 $3^{\text {rd }}$ Ed. New York, Mc Graw Hill;2010:454.

3. American College of Obstetrics and Gynecology. ACOG practice bulletin. Obstetric analgesia and anesthesia. Number 36, July 2002. American College of Obstetrics and Gynecology. Int J Gynaecol Obstet. 2002 Sep;78(3):321-35.

4. Daftary SN, Desai SV, Thanawala U, Bhide A, Levi J, Patki A et al. Programmed labor indegenous protocol to optimize labor outcome. J South Asian Federation Obstet Gynecol. 2009 Apr 25;1(1):61-4.

5. World Health Organization. WHO recommendations for the prevention and treatment of postpartum haemorrhage. 2012. WHO: Geneva, Switzerland. Available

at http://apps.who.int/iris/bitstream/10665/75411/1/978 9241548502_eng.pdf

6. Shaikh AF, Bhagat N, Bahagat K, Pandya M, Daftary S. Programmed labor for optimizing labour and delivery: a multicentric study. Indian $\mathrm{J}$ Obstet Gynaecol Res. 2015;2(3):169-73.

7. Jyoti M, Singhal P, Choudhary D. Programmed labor. J Obstet Gynecol India. 2006;56:53.

8. Mir S, Aziz R. Programmed labour and its outcome. Hypertension. 2011 Jan;4:5.

9. Manoj A, Sivashanmugam T, Ghose S, Gowda M, Maurya DK. Maternal outcome in programmed labour: a randomized control trial. Indian Medical Gazette. 2012

10. Yuel VI, Kaur V, Kaur D. Programmed labor for optimizing labor and delivery. JK Sci. 2008;10(3).

Cite this article as: Alam A, Goswami S. A comparative study of the effects of programmed labour protocol and expectant management of labour. Int J Reprod Contracept Obstet Gynecol 2017;6: 5536-9. 